\title{
TRH Gene Product
}

National Cancer Institute

\section{Source}

National Cancer Institute. TRH Gene Product. NCI Thesaurus. Code C136412.

A protein encoded by the TRH gene. 